\title{
Factors associated with desire to quit smoking among Estonian physicians: Cross-sectional data of 2002 and 2014
}

\author{
Mariliis Põld ${ }^{1}$, Kersti Pärna ${ }^{1}$
}

\begin{abstract}
INTRODUCTION Smoking is a major health threat and quitting smoking would be a notable benefit. The aim of the present study was to explore factors associated with desire to quit smoking among Estonian physicians in 2002 and 2014.

METHODS Self-reported data of current smokers were drawn from Estonian physicians' cross-sectional postal surveys in $2002(n=322)$ and $2014(n=189)$. A logistic regression model was used to analyse the association between desire to quit smoking and factors related to smoking behaviour among 'current smokers'.

RESULTS The prevalence of desire to quit smoking among physicians was $55.3 \%$ in 2002 and $52.9 \%$ in 2014. Physicians who were concerned about harms of smoking, had higher odds for desire to quit compared with those who were not concerned $(\mathrm{OR}=9.06$; 95\% CI: 4.15-19.74). Compared to physicians with no quit attempts, odds for desire to give up smoking were significantly higher among physicians with quit attempts. Wish to set a good example was significantly associated with desire to quit ( $\mathrm{OR}=2.38 ; 95 \% \mathrm{CI}: 1.12-5.09)$. Compared to specialist doctors, dentists had higher odds for desire to quit smoking ( $\mathrm{OR}=2.42$; 95\% CI: $1.25-4.69)$.

CONCLUSIONS More than half of Estonian smoking physicians expressed the desire to quit. Desire to quit was associated with concern about harms of smoking, number of previous quit attempts, setting a good example, and medical specialty. The findings suggest that there is a need for smoking cessation counselling services that are addressed, especially for physicians in Estonia.
\end{abstract}

AFFILIATION

1 University of Tartu, Tartu, Estonia

CORRESPONDENCE TO Mariliis Põld. University of Tartu, Ravila 19, 50411 Tartu, Estonia.Email: pold.mariliis@ gmail.com

\section{KEYWORDS}

physicians, smoking, Estonia, desire to quit

Received: 29 December 2017

Revised: 29 June 2018

Accepted: 4 July 2018

\section{INTRODUCTION}

Smoking as a modifiable risk factor is associated with chronic diseases and is currently responsible for over 6 million deaths each year ${ }^{1,2}$. Quitting smoking would be a significant health benefit ${ }^{3}$ but is often difficult to achieve due to nicotine dependence ${ }^{4}$. Physicians have the opportunity and obligation to advise people on quitting smoking but at the same time have been shown to be less active in addressing patients' smoking when they are smokers themselves ${ }^{5,6}$.

A behaviour change, such as quitting smoking, demonstrates distinguishable stages, like those in the states-of-change model: pre-contemplation, contemplation, preparation, action and maintenance ${ }^{7}$. A person's attitude towards quitting smoking can be reflected by, for example, a person's desire or intention to quit ${ }^{8}$.

Intention to quit smoking has been associated with gender ${ }^{9}$, age ${ }^{10}$, education ${ }^{10}$, income ${ }^{10}$, number of previous quit attempts ${ }^{9,11,12}$, nicotine dependence 9 , alcohol consumption ${ }^{9}$ and environmental factors ${ }^{13}$. So, to facilitate smoking cessation among physicians, it is important to analyse quitting smoking among them.

In Estonia, smoking surveys ${ }^{14-17}$ have been carried out among physicians in 1978, 1982, 2002 and 2014. A definite decrease in smoking prevalence among physicians has been reported over the surveys period. Age-standardized prevalence of current smoking among younger than 65-years-old male physicians was $26.8 \%$ in 2002 and $15.3 \%$ in 2014 , while among female physicians it was $10.4 \%$ and $5.8 \%$, 
respectively ${ }^{18}$.

The aim of the present paper was to explore factors associated with desire to quit smoking among Estonian physicians who were 'current smokers' in 2002 and 2014.

\section{METHODS}

\section{Study design}

The data were drawn from Estonian physicians' cross-sectional smoking surveys conducted in 2002 and 2014. The surveys were carried out as postal questionnaires initially involving all practicing physicians in Estonia ( $n=4140$ in 2002, and $n=5666$ in 2014 ; crude response rates were $66.3 \%$ and $51.9 \%$, while corrected response rates were $67.8 \%$ and $53.1 \%$, respectively). The methods have been described thoroughly elsewhere ${ }^{17,19}$.

The current study sample was restricted to under 65-years-old 'current smoker' physicians, who gave answers regarding desire to quit smoking in 2002 $(\mathrm{n}=322)$ and in $2014(\mathrm{n}=189)$.

The surveys in 2002 and 2014 were approved by the Research Ethics Committee of the University of Tartu (Decisions No. 87/1 and 235/T-12, respectively). An informed consent form including a description of the study design and how the collected data would be used was sent to the recipients with the questionnaires. The form explained that participation in the study constituted consent, thus additional written consent was not obtained.

\section{Variables}

The main outcome indicator was desire to quit smoking (yes, no, cannot say). Factors associated with desire to quit smoking were: current smoking frequency, factors related to smoking behaviour, background characteristics, and study year. Smoking frequency was based on answers to several questions and classified as: 1) daily smokers (those who currently smoke every day), and 2) occasional smokers (those who currently smoke but not every day).

The following questions were used regarding factors related to smoking behaviour: concern (not concerned, concerned) about harms of smoking; number (none, $1-2,3-4, \geqslant 5$ ) of previous quit attempts; main reason (stress, strong withdrawal symptoms, alcohol consumption, weight gain, smoking in proximity, other) to restart smoking ; and motivation (personal health problems, material stimulus, wish to set a good example, other) to quit smoking. To determine reason to restart smoking and motivator to quit smoking, the respondents were required to check one answer from the list provided.

Background characteristics used in this study were the following: gender; age group in years $(\leqslant 34$, 35-44, 45-54, 55-64); ethnicity (Estonian, nonEstonian); place of residence (Tallinn, other city, rural); medical specialty (family physicians, specialist doctors, dentists); study year $(2002,2014)$.

\section{Data analysis}

Distributions of physicians by desire to quit smoking, smoking frequency, factors related to smoking behaviour and background characteristics were calculated along with the mean age of respondents and standard deviation. To determine association between desire to quit smoking and factors related to smoking behaviour, multiple logistic regression analysis was used. Dichotomized desire to quit smoking (yes; no: no and cannot say) was used as dependent variable and all other factors as explanatory variables in logistic regression models. Logistic regression analysis was performed with two models, Model 1 (adjusted for gender, age and year) and Model 2 (adjusted for all explanatory variables). Odds ratios (OR) and 95\% confidence intervals (CI) were calculated.

Questionnaires with lacking smoking status values $(\mathrm{n}=11)$ and data concerning desire to quit smoking $(n=12)$ were excluded from the analysis. In total, 511 questionnaires were included in the final analysis. Questionnaires without information concerning factors related to smoking behaviour and background characteristics were excluded from the logistic regression models.

\section{RESULTS}

\section{Characteristics of the sample}

Number of respondents was 322 in 2002 and 189 in 2014. Age range of physicians was 27-64 years in 2002 and 25-64 years in 2014, with mean age $45.4 \pm$ 9.3 and $49.7 \pm 10.4$, respectively. In both study years, more than two-thirds of smoking respondents were females (67.1\% in 2002, and $65.1 \%$ in 2014 ).

Overview of background characteristics is 
provided in Table 1. In 2002, the highest proportion of respondents was in age group 35-44 (36.0\%), while in 2014 it was in age group 55-64 (40.2\%). Most of the respondents were of Estonian ethnicity (82.9\% in 2002, and $78.3 \%$ in 2014 ) and nearly half of respondents (43.8\% in 2002, and $43.4 \%$ in 2014 ) were residents of other cities (excluding Tallinn). More than half of respondents were specialist doctors ( $58.4 \%$ in 2002 , and $56.6 \%$ in 2014 ).

The prevalence of desire to quit smoking was
$55.3 \%$ in 2002 and $52.9 \%$ in 2014 (Table 2). In 2002, almost a third (30.1\%) remained undecided whereas in 2014 this proportion was $22.2 \%$. Among 'current smokers', the majority were daily smokers in both study years (64.3\% in 2002, and $77.8 \%$ in 2014 ). Majority of physicians (77.3\% in 2002, and $79.4 \%$ in 2014) were concerned about the harms of smoking (Table 2). In 2002 the percentage of physicians who had 3-4 previous smoking quit attempts was $21.4 \%$, while in 2014 it was $16.4 \%$. Among reasons to restart

Table 1. Distribution of background characteristics (n, \%) among smoking physicians by gender and study year in Estonia, $2002(\mathrm{n}=322)$ and $2014(\mathrm{n}=189)$

\begin{tabular}{|c|c|c|c|c|c|c|c|c|c|c|c|c|}
\hline \multirow[b]{3}{*}{ Characteristic } & \multicolumn{6}{|c|}{2002} & \multicolumn{6}{|c|}{2011} \\
\hline & \multicolumn{2}{|c|}{ Men } & \multicolumn{2}{|c|}{ Women } & \multicolumn{2}{|c|}{ Total } & \multicolumn{2}{|c|}{ Ven } & \multicolumn{2}{|c|}{ Women } & \multicolumn{2}{|c|}{ Total } \\
\hline & n & $\%$ & n & $\%$ & n & $\%$ & n & $\%$ & $n$ & $\%$ & n & $\%$ \\
\hline \multicolumn{13}{|l|}{ Age group (Years) } \\
\hline$\leq 34$ & 18 & 17.0 & 27 & 12.5 & 45 & 14.0 & 12 & 18.2 & 11 & 8.9 & 23 & 12.2 \\
\hline $35-44$ & 35 & 33.0 & 81 & 37.5 & 116 & 36.0 & 7 & 10.6 & 18 & 14.6 & 25 & 13.2 \\
\hline $45-54$ & 35 & 33.0 & 67 & 31.0 & 102 & 31.7 & 22 & 33.3 & 43 & 35.0 & 65 & 34.4 \\
\hline $55-64$ & 18 & 17.0 & 41 & 19.0 & 59 & 18.3 & 25 & 37.9 & 51 & 41.5 & 76 & 40.2 \\
\hline \multicolumn{13}{|l|}{ Ethnicity } \\
\hline Estonian & 85 & 81.0 & 182 & 84.3 & 267 & 82.9 & 46 & 69.7 & 102 & 82.9 & 148 & 78.3 \\
\hline Non-Estonian & 20 & 19.0 & 34 & 15.7 & 54 & 16.8 & 20 & 30.3 & 21 & 17.1 & 41 & 21.7 \\
\hline \multicolumn{13}{|l|}{ Place of residence } \\
\hline Tallinn & 39 & 37.5 & 82 & 40.6 & 121 & 38.1 & 28 & 42.4 & 50 & 40.7 & 78 & 41.3 \\
\hline Other city & 43 & 41.3 & 98 & 48.5 & 141 & 44.3 & 28 & 42.4 & 54 & 43.9 & 82 & 43.4 \\
\hline Non-urban & 22 & 21.2 & 22 & 10.9 & 56 & 17.6 & 10 & 15.2 & 19 & 15.4 & 29 & 15.3 \\
\hline \multicolumn{13}{|l|}{ Medical specialty } \\
\hline Family physician & 13 & 12.7 & 32 & 15.5 & 45 & 14.6 & 5 & 7.7 & 31 & 25.6 & 36 & 19.3 \\
\hline Specialist doctor & 77 & 75.5 & 111 & 53.9 & 188 & 60.8 & 47 & 72.3 & 60 & 49.6 & 107 & 57.2 \\
\hline Dentist & 12 & 11.8 & 63 & 30.6 & 76 & 24.6 & 13 & 20.0 & 30 & 24.8 & 44 & 23.5 \\
\hline
\end{tabular}

Table 2. Distribution of main outcome (desire to quit smoking), smoking frequency and factors related to smoking behaviour (n, \%) among physicians by gender and study year in Estonia, $2002(\mathrm{n}=322)$ and $2014(\mathrm{n}=189)$

\begin{tabular}{|c|c|c|c|c|c|c|c|c|c|c|c|c|}
\hline \multirow[b]{3}{*}{ Characteristic } & \multicolumn{6}{|c|}{2002} & \multicolumn{6}{|c|}{2011} \\
\hline & \multicolumn{2}{|c|}{ Ven } & \multicolumn{2}{|c|}{ Women } & \multicolumn{2}{|c|}{ Total } & \multicolumn{2}{|c|}{ Men } & \multicolumn{2}{|c|}{ Women } & \multicolumn{2}{|c|}{ Total } \\
\hline & n & $\%$ & n & $\%$ & n & $\%$ & n & $\%$ & n & $\%$ & $n$ & $\%$ \\
\hline \multicolumn{13}{|c|}{ Desire to quit smoking } \\
\hline Yes & 56 & 52.9 & 122 & 56.2 & 178 & 55.3 & 39 & 59.1 & 61 & 49.6 & 100 & 52.9 \\
\hline No & 19 & 17.9 & 28 & 13.4 & 47 & 14.6 & 19 & 28.8 & 28 & 22.8 & 47 & 24.9 \\
\hline Cannot say & 31 & 29.2 & 66 & 30.4 & 97 & 30.1 & 8 & 12.1 & 34 & 27.6 & 42 & 22.2 \\
\hline \multicolumn{13}{|c|}{ Smoking frequency } \\
\hline Occasional & 30 & 28.3 & 85 & 39.4 & 115 & 35.7 & 15 & 22.7 & 27 & 22.0 & 42 & 22.2 \\
\hline Daily & 76 & 71.7 & 131 & 60.6 & 207 & 64.3 & 51 & 77.3 & 96 & 78.0 & 147 & 77.8 \\
\hline \multicolumn{13}{|c|}{ Concern about harms of smoking } \\
\hline Concerned & 78 & 77.2 & 171 & 79.9 & 249 & 79.0 & 53 & 82.8 & 97 & 78.9 & 150 & 80.2 \\
\hline Not concerned & 23 & 22.8 & 43 & 20.1 & 66 & 21.0 & 11 & 17.2 & 26 & 21.1 & 37 & 19.8 \\
\hline
\end{tabular}


Table 2. Continued

\begin{tabular}{|c|c|c|c|c|c|c|c|c|c|c|c|c|}
\hline \multirow[b]{3}{*}{ Characteristic } & \multicolumn{6}{|c|}{2002} & \multicolumn{6}{|c|}{2014} \\
\hline & \multicolumn{2}{|c|}{ Men } & \multicolumn{2}{|c|}{ Women } & \multicolumn{2}{|c|}{ Total } & \multicolumn{2}{|c|}{ Ven } & \multicolumn{2}{|c|}{ Women } & \multicolumn{2}{|c|}{ Total } \\
\hline & n & $\%$ & n & $\%$ & n & $\%$ & n & $\%$ & n & $\%$ & n & $\%$ \\
\hline \multicolumn{13}{|l|}{ Previous quit attempts } \\
\hline None & 29 & 27.4 & 66 & 31.1 & 95 & 29.9 & 18 & 28.6 & 31 & 26.1 & 49 & 26.9 \\
\hline $1-2$ & 35 & 33.0 & 85 & 40.1 & 120 & 37.7 & 21 & 33.3 & 59 & 49.6 & 80 & 44.0 \\
\hline $3-4$ & 25 & 23.6 & 44 & 20.8 & 69 & 21.7 & 14 & 22.2 & 17 & 14.3 & 31 & 17.0 \\
\hline 5 or more & 17 & 16.0 & 17 & 8.0 & 34 & 10.7 & 10 & 15.9 & 12 & 10.1 & 22 & 12.1 \\
\hline \multicolumn{13}{|c|}{ Main reason to restart smoking } \\
\hline Stress & 32 & 34.8 & 67 & 39.6 & 99 & 37.9 & 23 & 43.4 & 44 & 42.7 & 67 & 42.9 \\
\hline Withdrawal symptoms & 10 & 10.9 & 8 & 4.7 & 18 & 6.9 & 11 & 20.8 & 9 & 8.7 & 20 & 12.8 \\
\hline Alcohol consumption & 7 & 7.6 & 3 & 1.8 & 10 & 3.8 & 9 & 17.0 & 2 & 1.9 & 11 & 7.1 \\
\hline Weight gain & 8 & 8.7 & 19 & 11.2 & 27 & 10.3 & 4 & 7.5 & 17 & 16.5 & 21 & 13.5 \\
\hline Smoking in proximity & 19 & 20.7 & 44 & 26.0 & 63 & 24.1 & 4 & 7.5 & 20 & 19.4 & 24 & 15.4 \\
\hline Other & 16 & 17.4 & 28 & 16.6 & 44 & 16.9 & 2 & 3.8 & 11 & 10.7 & 13 & 8.3 \\
\hline \multicolumn{13}{|l|}{ Motivation to quit smoking } \\
\hline Personal health problems & 65 & 67.7 & 138 & 71.9 & 203 & 70.5 & 42 & 75.0 & 78 & 74.3 & 120 & 74.5 \\
\hline Material stimulus & 7 & 7.3 & 5 & 2.6 & 12 & 4.2 & 4 & 7.1 & 1 & 1.0 & 5 & 3.1 \\
\hline Wish to set a good example & 14 & 14.6 & 33 & 17.2 & 47 & 16.3 & 6 & 10.7 & 16 & 15.2 & 22 & 13.7 \\
\hline Other & 10 & 10.4 & 16 & 8.3 & 26 & 9.0 & 4 & 7.1 & 10 & 9.5 & 14 & 8.7 \\
\hline
\end{tabular}

smoking, stress was most prevalent in both study years $(30.7 \%$ in 2002 , and $35.4 \%$ in 2014 ), followed by smoking in proximity and weight gain. Two-thirds of physicians (63.0\% in 2002, and $63.5 \%$ in 2014 ) stated that personal health problems could motivate them to quit smoking. Wish to set a good example was the second most prevalent motivator for quitting.

\section{Association between desire to quit smoking and factors related to smoking}

According to the results of the fully adjusted logistic regression model, desire to quit smoking was significantly associated with being concerned about the harms of smoking, number of previous quit attempts, wish to set a good example, and medical specialty (Table 3 ). After full adjustment, daily smoking appeared not to be associated with the higher desire to quit smoking but the wish to set a good example was.

Compared to the physicians who were not concerned about harms of smoking, odds for desire to quit smoking were significantly higher among physicians being concerned about harms of smoking $(\mathrm{OR}=9.06 ; 95 \%$ CI: $4.15-19.74)$. Compared to physicians who had not tried to quit smoking, odds for desire to quit smoking were significantly higher

Table 3. Pooled analysis of the association between desire to quit smoking (yes vs no) and smoking frequency, factors related to smoking behaviour, background characteristics, and study year among physicians in Estonia, $2002(n=322)$ and $2014(n=189)$

\begin{tabular}{|c|c|c|c|c|}
\hline \multirow[b]{2}{*}{ Characteristic } & \multicolumn{2}{|c|}{ Vodel $1^{\mathrm{a}}$} & \multicolumn{2}{|c|}{ Vodel $2^{b}$} \\
\hline & OR & $95^{\circ} \% \mathrm{CI}$ & OR & $95 \% \mathrm{CI}$ \\
\hline \multicolumn{5}{|c|}{ Smoking frequency } \\
\hline Occasional & 1.00 & & 1.00 & \\
\hline Daily & 1.83 & $1.24-2.71$ & 1.56 & $0.87-2.80$ \\
\hline \multicolumn{5}{|c|}{ Factors related to smoking behaviour } \\
\hline \multicolumn{5}{|c|}{ Concern about harms of smoking } \\
\hline Not concerned & 1.00 & & 1.00 & \\
\hline Concerned & 7.95 & $4.63-13.66$ & 9.06 & $4.15-19.74$ \\
\hline
\end{tabular}


Table 3. Continued

\begin{tabular}{|c|c|c|c|c|}
\hline \multirow[b]{2}{*}{ Characteristic } & \multicolumn{2}{|c|}{ Vodel $1^{\mathrm{a}}$} & \multicolumn{2}{|c|}{ Model $2^{b}$} \\
\hline & OR & $95 \% \mathrm{CI}$ & OR & $95 \% \mathrm{CI}$ \\
\hline \multicolumn{5}{|c|}{ Number of previous quit attempts } \\
\hline None & 1.00 & & 1.00 & \\
\hline $1-2$ & 2.37 & $1.51-3.73$ & 2.22 & $1.18-4.17$ \\
\hline $3-4$ & 9.31 & $5.06-17.13$ & 10.58 & $4.51-24.79$ \\
\hline 5 or more & 13.88 & $6.03-31.95$ & 9.81 & $3.63-26.49$ \\
\hline \multicolumn{5}{|l|}{ Main reason to restart smoking } \\
\hline Stress & 1.00 & & 1.00 & \\
\hline Strong withdrawal symptoms & 1.11 & $0.53-2.33$ & 0.75 & $0.29-1.99$ \\
\hline Alcohol consumption & 0.85 & $0.33-2.18$ & 1.66 & $0.43-6.26$ \\
\hline Weight gain & 0.64 & $0.33-1.23$ & 0.69 & $0.29-1.66$ \\
\hline Smoking in proximity & 0.80 & $0.46-1.37$ & 0.72 & $0.35-1.47$ \\
\hline Other & 0.60 & $0.32-1.11$ & 0.81 & $0.35-1.88$ \\
\hline \multicolumn{5}{|l|}{ Motivation to quit smoking } \\
\hline Personal health problems & 1.00 & & 1.00 & \\
\hline Material stimulus & 0.71 & $0.26-1.90$ & 0.38 & $0.08-1.80$ \\
\hline Wish to set a good example & 1.46 & $0.85-2.51$ & 2.38 & $1.12-5.09$ \\
\hline Other & 1.05 & $0.54-2.04$ & 1.99 & $0.76-5.25$ \\
\hline \multicolumn{5}{|c|}{ Background characteristics } \\
\hline \multicolumn{5}{|l|}{ Gender } \\
\hline Male & 1.00 & & 1.00 & \\
\hline Female & 0.96 & $0.66-1.39$ & 1.19 & $0.66-2.12$ \\
\hline \multicolumn{5}{|l|}{ Age group } \\
\hline$\leq 34$ & 1.00 & & 1.00 & \\
\hline $35-44$ & 1.01 & $0.56-1.82$ & 0.77 & $0.32-1.82$ \\
\hline $45-54$ & 0.94 & $0.53-1.66$ & 0.87 & $0.38-2.01$ \\
\hline $55-64$ & 0.70 & $0.38-1.26$ & 0.69 & $0.29-1.68$ \\
\hline \multicolumn{5}{|l|}{ Ethnicity } \\
\hline Estonian & 1.00 & & 1.00 & \\
\hline Non-Estonian & 1.23 & $0.78-1.94$ & 1.54 & $0.76-3.09$ \\
\hline \multicolumn{5}{|l|}{ Place of residence } \\
\hline Tallinn & 1.00 & & 1.00 & \\
\hline Other city & 0.94 & $0.64-1.37$ & 0.87 & $0.49-1.54$ \\
\hline Non-urban & 1.53 & $0.90-2.59$ & 0.96 & $0.46-2.01$ \\
\hline \multicolumn{5}{|l|}{ Medical specialty } \\
\hline Specialist doctor & 1.00 & & 1.00 & \\
\hline Family physician & 1.58 & $0.95-2.62$ & 1.88 & $0.89-4.01$ \\
\hline Dentist & 1.76 & $1.12-2.76$ & 2.42 & $1.25-4.69$ \\
\hline \multicolumn{5}{|l|}{ Study year } \\
\hline 2002 & 1.00 & & 1.00 & \\
\hline 2014 & 0.99 & $0.68-1.44$ & 0.95 & $0.54-1.68$ \\
\hline
\end{tabular}

a Model 1 adjusted for gender, age and year. b Model 2 adjusted for all the other characteristics in the Table.

among physicians who had $1-2,3-4$, and $\geqslant 5$ attempts to give up smoking. Compared to physicians who agreed with the statement that health problems are the best motivators to quit smoking, odds for desire to stop smoking were significantly higher among physicians who agreed that setting a good example was the main reason to quit smoking $(\mathrm{OR}=2.38$; 95\% CI: 1.12-5.09). Compared to specialist doctors, desire to stop smoking was significantly higher among dentists (OR=2.42; 95\% CI: $1.25-4.69)$. 
No significant associations were found with any factors listed under main reason to restart smoking, with almost all factors listed as motivators to quit smoking (except wish to set a good example), with sociodemographic factors (gender, age, ethnicity, and place of residency), and with study year.

\section{DISCUSSION}

In the current paper, factors associated with desire to quit smoking were explored among Estonian physicians in 2002 and 2014.

\section{Prevalence of desire to quit smoking and factors related to smoking behaviour}

According to the results of the study, more than half of smoking physicians indicated a desire to quit smoking in 2002 and 2014. These proportions are comparable, for example, to those of Poland in 2004 where about $60 \%$ of physicians wished to quit, but lower than those of the Czech Republic in 1995 where about $75 \%$ of smokers intended to quit ${ }^{20}$. Although the proportion of physicians who had a desire to quit smoking was similar in both years among 'current smoker' physicians in Estonia, the prevalence of daily smokers and the proportion of those who did not want to quit smoking was higher in 2014 than in 2002. The higher prevalence of daily smokers might indicate smokers with a stronger nicotine dependence who were not determined to quit.

Studies concerning quitting smoking usually measure intention to quit, not desire to quit. However, both reflect the general attitude towards quitting $^{8}$. Desire to quit has been stated as an important factor in smoking cessation as it reflects motivation but, on the other hand, is different from actually intending to quit and has been merely seen to predict quit attempts and not the success of cessation $^{7,21}$. The questionnaire used in this study explored only desire to quit smoking because the survey focus was on smoking behaviour in general.

In this paper, stress, smoking in proximity and withdrawal symptoms were reported to be the most important reasons for restarting smoking. These findings are in accordance with previous results ${ }^{22}$. Smoking in proximity was the second most mentioned reason but the prevalence of this declined notably from 2002 to 2014 . The decline might be due to smoking decline in general but also because in Estonia smoking in health care establishments is prohibited. The current Tobacco Act, enforced in 2005 and revised several times, is in accordance with EU and WHO tobacco policies and places extensive restrictions to smoking in public and in establishments like schools, hospitals and restaurants.

In our study, personal health problems and wish to set a good example were the most prevalent motivators for quitting. Previous findings also suggested that concern for personal health and wishing to set a good example are the most important reasons among medical staff and the general population ${ }^{23,24}$.

Previous studies have also shown a connection between nicotine dependence and smoking cessation $^{22,23,25}$. In the Estonian physicians' smoking surveys, nicotine dependence was measured only in 2014 , and so it was not possible to include these data in the present study.

\section{Associations between desire to quit smoking and factors related to smoking behaviour}

Desire to quit smoking was found to be significantly associated with being concerned about harms of smoking, number of previous quit attempts, and wish to set a good example. These findings are in accordance with previous studies ${ }^{10,25}$. Attempts to quit have been shown to be associated with intention to quit and are considered an important predictor of cessation success $^{12,25}$. In the present study, compared to respondents who had no quit attempts, physicians who had $1-2,3-4$ or $\geqslant 5$ quit attempts, had higher odds for desire to quit. Similarly, to previous findings, Estonian physicians who were concerned about the harms of smoking were more likely to desire to quit ${ }^{10,25}$. These associations could indicate that a person is aware of the damaging effects of smoking, is motivated to quit, has tried but failed and so is in need of cessation support.

None of the reasons for relapse was significantly associated with desire to quit smoking in this study. In previous studies, alcohol consumption has been found to be associated with intention to quit smoking. Smokers who had higher number of drinks per week were less likely to intend to quit smoking ${ }^{10}$. The questionnaire that was used to collect data for 
this study did not measure alcohol consumption.

In motivators for quitting, only wish to set a good example was significantly associated with desire to quit smoking among physicians in Estonia. As doctors are considered role models, it was expected that setting a good example would be a significant finding among Estonian physicians, as well. Material stimulus was not significantly associated with desire to quit in our study. This was somewhat expected as physicians can be considered as having higher socioeconomic status. However, in contrast, among the general population, material incentives have been described as important factors in quitting smoking, thus increasing the prices of tobacco products should be prioritized when designing tobacco control programs $^{26,27}$.

The association between desire to quit smoking and medical specialty showed that compared to specialist doctors, dentists had significantly higher odds for desire to quit smoking. The association was not significant for family physicians. While this last aspect was unexpected, the finding for dentists was predictable as they are in close contact with the patient and therefore aware of the devastating effects of smoking on oral health. The lack of a notable difference between family physicians and medical specialists could be explained by the distribution of specialties among physicians - only about $10 \%$ of medical specialists were surgeons in this study. It has been shown elsewhere that, among male physicians, surgeons had the highest prevalence of smoking compared to other specialities ${ }^{28}$.

No association was found between desire to quit smoking, gender and age among physicians in Estonia. There is little information about whether gender is associated with desire and intent to quit smoking worldwide but the findings concerning successful cessation tend to show that women are less likely to stay abstinent ${ }^{23,25,29,30}$. It is possible that among women who desire to quit, less have serious health conditions that would otherwise motivate them to abstain from relapses. However, as men tend to be less active in seeking medical help, their health problems could be more serious and so motivating them to remain abstinent. Older age has also been shown to be a predictor of successful cessation, with increased cessation rates observed among those who were aged 45 years or older ${ }^{23}$. However, intention to quit has been shown to decrease with increasing age $^{25}$. These findings might reflect a relationship between health issues and quitting smoking, since it has been shown that smoking physicians tend to believe that many people have smoked all their lives to an old age and did not become ill, hence smoking is not as dangerous as experts declare ${ }^{18}$.

In this study, no association was found between desire to quit smoking and study year. This finding was unexpected since between 2002 and 2014 several major legislative changes occurred in terms of tobacco policy in Estonia. Also, most of the major hospitals joined the network for tobacco-free health services $^{31}$ and now promote smoking cessation among their staff. However, smoking in health care establishments has been prohibited by the Tobacco Act in force from 2005.

\section{Limitations and strengths}

First, this study relied on self-reported data, thus self-representation bias should be considered since smokers tend to underestimate the amount smoked ${ }^{32}$. Second, the response rates of $67.8 \%$ in 2002 and $53.1 \%$ in 2014 may indicate underrepresentation of smokers. Third, as smoking prevalence has been declining, the sub-samples of smoking physicians were small. This may have led to limited statistical power in detecting differences. Despite these limitations, Estonian physicians' smoking surveys provide excellent opportunity to analyse smoking behaviour as physicians can be considered as a homogenous sample and the survey methods were similar in both years.

\section{CONCLUSIONS}

More than half of Estonian physicians who smoked had a desire to quit smoking and nearly one-third was not sure about this. Desire to quit smoking was significantly associated with being concerned about harms of smoking, number of previous quit attempts, setting a good example and medical specialty.

The findings indicate that there is a need for smoking cessation counselling services that are addressed, especially for physicians in Estonia. In addition to face-to-face based counselling, alternatives like telephone and internet-based interventions should be considered to motivate quitting and support abstinence among physicians. 


\section{REFERENCES}

1. WHO global report on trends in prevalence of tobacco smoking 2015. Geneva:WHO;2015.

2. Reitsma MB, Fullman N, Ng M, Salama JS, Abajobir A, Abate KH, et al. Smoking prevalence and attributable disease burden in 195 countries and territories, 19902015: a systematic analysis from the Global Burden of Disease Study 2015. Lancet. 2017;389:1885-906.

3. Jha P, Ramasundarahettige C, Landsman V, Rostron B, Thun M, Anderson RN, et al. 21st-century hazards of smoking and benefits of cessation in the United States. N Engl J Med 2013;368:341-50. doi:10.1056/nejmsa1211128

4. DiFranza JR, Savageau JA, Rigotti NA, Fletcher K, Ockene JK, McNeill AD, et al. Development of symptoms of tobacco dependence in youths: 30 month follow up data from the DANDY study. Tob Control. 2002;11:22835. doi:10.1136/tc.11.3.228

5. Meshefedjian GA, Gervais A, Tremblay M, Villeneuve D, O'Loughlin J. Physician smoking status may influence cessation counseling practices. Can J Public Heal. 2010;101:290-3.

6. Alajmi B, Abu-hammad O, Al-sharrad A, Dar-odeh N. Tobacco cessation support among dentists: A crosssectional survey in Saudi Arabia and Kuwait. Tob Prev Cessat. 2017;3:121. doi: 10.18332/tpc/75795

7. Prochaska JO, DiClemente CC, Norcross JC. In search of how people change: applications to addictive behaviors. J Addict Nurs 1993;5(1):2-16. doi: 10.3109/10884609309149692

8. Malle BF, Moses LJ, Baldwin DA, editors. Intentions and Intentionality. The MIT Press; 2001.

9. Marques-Vidal P, Melich-Cerveira J, Paccaud F, Waeber G, Vollenweider P, Cornuz J. Prevalence and factors associated with difficulty and intention to quit smoking in Switzerland. BMC Public Health 2011;11(1):227. doi:10.1186/1471-2458-11-227

10. Myung SK, Seo HG, Cheong YS, Park S, Lee WB, Fong GT. Association of sociodemographic factors, smokingrelated beliefs, and smoking restrictions with intention to quit smoking in Korean adults: findings from the ITC Korea survey. J Epidemiol 2012;22(1):21-7. doi:10.2188/jea.je20110026

11. Haddad LG, Petro-Nustas W. Predictors of Intention to Quit. Can J Public Heal. 2006;97:9-13.

12. Hyland A. Individual-level predictors of cessation behaviours among participants in the International Tobacco Control (ITC) Four Country Survey. Tob Control 2006;15(suppl_3).doi/10.1136/tc.2005.013516

13. Myung SK, McDonnell DD, Kazinets G, Seo HG, Moskowitz JM. Relationships between household smoking restrictions and intention to quit smoking among Korean American male smokers in California. J Korean Med Sci. 2010;25(2):245-50. doi:10.3346/jkms.2010.25.2.245
14. Väärt E, Vahtra M, Rahu M, et al. Eesti arstkonna suitsetamishõlmavuse ankeetküsitlus. Nõukogude Eesti Tevishoid 1979;58:279-81.

15. Rahu M, Raudsepp J. Teine Eesti NSV arstkonna suitsetamislevimuse ankeetküsitlus 1982. aastal. Nõukogude Eesti Tervishoid 1986;65:258-61.

16. Pärna K, Rahu K, Rahu M. Smoking habits and attitudes towards smoking among Estonian physicians. Public Health 2005;119(5):390-9. doi:10.1016/j.puhe.2004.07.005

17. Pärna K, Põld M, Ringmets I. Trends in smoking behaviour among Estonian physicians in 19822014. BMC Public Health 2017;18(1):55. doi:10.1186/s12889-017-4596-x

18. Põld M, Pärna K. Smoking prevalence and attitudes towards smoking among Estonian physicians: results from cross-sectional studies in 2002 and 2014. BMJ Open 2017;7(11):e017197. doi:10.1136/bmjopen-2017-017197

19. Pärna K, Rahu K, Barengo NC, Rahu M, Sandström $\mathrm{PH}$, Jormanainen VJ, et al. Comparison of knowledge, attitudes and behaviour regarding smoking among Estonian and Finnish physicians. Soz Praventivmed. 2005;50(6):378-88. doi:10.1007/s00038-005-4089-z

20. Abdullah AS, Stillman FA, Yang L, Luo H, Zhang Z, Samet JM. Tobacco use and smoking cessation practices among physicians in developing countries: A literature review (1987-2010). Int J Environ Res Public Health. 2014;11(1):429-55. doi:10.3390/ijerph110100429

21. Smit ES, Hoving C, Schelleman-Offermans K, West R, de Vries H. Predictors of successful and unsuccessful quit attempts among smokers motivated to quit. Addict Behav 2014;39(9):1318-24. doi:10.1016/j.addbeh.2014.04.017

22. Al-Turkstani AHM, Alkail BA, Hegazy AA, Asiri SI. Knowledge, attitude, and practice among primary healthcare physicians toward smoking cessation in Makkah, Saudi Arabia. Int J Med Sci Public Heal 2016;5(4):71424. doi:10.5455/ijmsph.2016.13112015224

23. Hyland A, Li Q, Bauer JE, Giovino GA, Steger C, Cummings KM. Predictors of cessation in a cohort of current and former smokers followed over 13 years. Nicotine Tob Res. 2004;6(6):363-9. doi:10.1080/14622200412331320761

24. Bennasar Veny M, Pericas Beltrán J, González Torrente S, Segui González P, Aguiló Pons A, Tauler Riera P. Selfperceived factors associated with smoking cessation among primary health care nurses: a qualitative study. Rev Lat Am Enfermagem 2011;19(6):1437-44. doi:10.1590/s0104-11692011000600022

25. Vangeli E, Stapleton J, Smit ES, Borland R, West R. Predictors of attempts to stop smoking and their success in adult general population samples: A systematic review. Addiction. 2011;106(12):2110-21. doi:10.1111/j.1360-0443.2011.03565.x 
26. Hill S, Amos A, Clifford D, Platt S. Impact of tobacco control interventions on socioeconomic inequalities in smoking: review of the evidence. Tob Control. 2014;23:e89-e97. doi:10.1136/tobaccocontrol-2013-051110

27. Hoffman SJ, Tan C. Overview of systematic reviews on the health-related effects of government tobacco control policies. BMC Public Health. 2015;15(1):744. doi:10.1186/s12889-015-2041-6

28. Yao T, Ong M, Lee A, Jiang Y, Mao Z. Smoking knowledge, attitudes, behavior, and associated factors among Chinese male surgeons. World J Surg. 2009;33(5):910-7. doi:10.1007/s00268-009-9938-0

29. Caponnetto P, Polosa R. Common predictors of smoking cessation in clinical practice. Respir Med. 2008;102(8):1182-92. doi:10.1016/j.rmed.2008.02.017

30. Piper ME, Cook JW, Schlam TR, Jorenby DE, Smith SS, Bolt DM, et al. Gender, race, and education differences in abstinence rates among participants in two randomized smoking cessation trials. Nicotine Tob Res. 2010;12:64757. doi:10.1093/ntr/ntq067

31. ENSH. Global Network for Tobacco Free Health Care Services. http://www.ensh.org/members.php. Accesed June 29, 2018.

32. Patrick DL, Cheadle A, Thompson DC, Diehr P, Koepsell T, Kinne S. The validity of self-reported smoking: A review and meta-analysis. Am J Public Health. 1994;84:1086-93. doi:10.2105/ajph.84.7.1086

ACKNOWLEDGEMENTS

The authors would like to thank the entire team involved in designing and conducting the survey in 2002 and 2014

CONFLICTS OF INTEREST Both authors report grants from the Estonian Research Council during the conduct of the study. The authors have completed and submitted an ICMJE form for disclosure of potential conflicts of interest. The authors declare that they have no competing interests, financial or otherwise, related to the current work.

FUNDING

This work was supported by the Estonian Research Council (Grant Numbers PUT-299 and IUT34-17).

PROVENANCE AND PEER REVIEW

Not commissioned; externally peer reviewed. 